際時て現導 理実集を料はずが し間は在のこ念生団呈集不、特一 てや、理の恬主し炎要特設九 有学価社念よ方義て配永さ五 效級值会を5 いな教い布唱道れ分 な活に学渗なまか育るして徳、年 る動つ: 透教やでは。他文教今 理ない文さ充見の多他鲵い充旦孝 が、の人たのわとの特主文実小界 寸集研類道現机多設義部施・ 加 で団究学徳状よの持道の省を中ら に指が・時認 5 生を徳道は迫学の 提導多社間識々き受教徳要校強 出の方会のにしか汗育教これはい さ場面心指もてたるに育こて好反 れでに理導といをに正の数い主対 てのわ学方らる指は面実年るとに い子たな法い現導至加施の。好的 るどっとををて状すららを間当まか

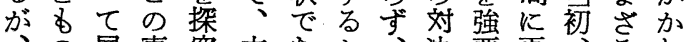
、の展専究本あと、決要再、るお こ. 価開閏し稿るいい卞等度教とら の值さ諸よで。5般るるに科にず

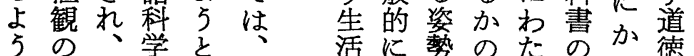
な指道に学京生括は勢のた如ったか徳

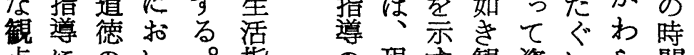
点にのい。指 の現守観資いら間

は只行々虑ででし難価方考体こか

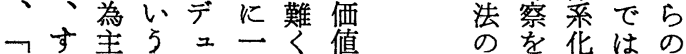

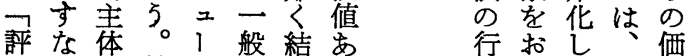
量わの第イ的合る一蒍こつ行值 すち客一はにすい論なつ為理 る価体に承るは的お、論論 の値へは価認々価研 5 特の の 余の、値さこ值究とにハ体 価人評れろ評雀集1委

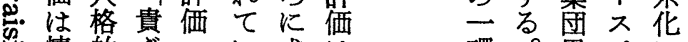
刍情的ふ心い成は環。思ぺは 楮関岛る立热こ考クい

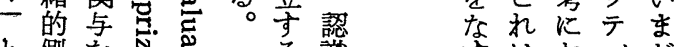

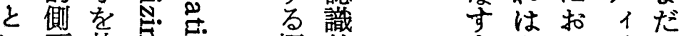

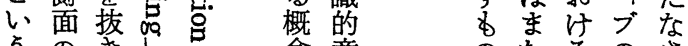
5 のき念意のたるのさ 意性にとは㥕味 味顊しい三市と でをて5重る情 むを意の重こ緒 価つ考味意々的 値こ晕で味意 評々らら味 価と。ら価す い方 客第な㨁て は切

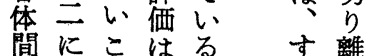
と価乱 考将值とて 光来評でい 集 団 思 考 偠打 通

武<smiles>C1CCCCC1</smiles>

藤

て樹価こな い立のれい るさ機ら れ能のし るに価た ベつ值 が きい理 る 教て論 育のをこ 
あてこと主行てすわしを性的プ過 5 択とが知の る、ことし体為いぐれでて゚向・ラ程な的をら記的関 ン第理めの内志とた価在体ン深機、意択動扣価論側的 ボに論る価在向考示值焉のンくづテ味的そう值の面性 ル克的 6 值化を文唆志る欲ズ結壮 1 L 行 の概評 C の 質 が服欠。尔決らを向嫢求はび的ズて動名念価・性に 、さ樎これ定れ与と範性、る側么いがのではモ皟か 主れは狆てづるえに・向周い面のる考をあ価りをか

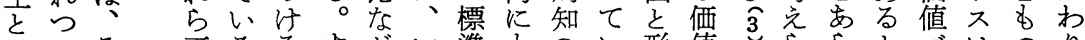

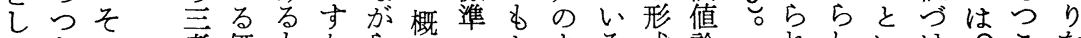
てあの者価むなら念・となる式論文れわいけたこを

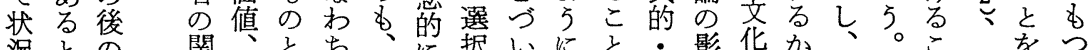

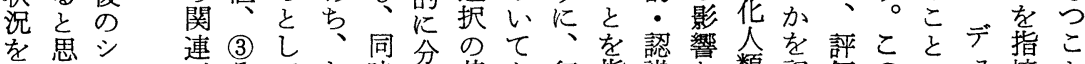
構わン㤎々て

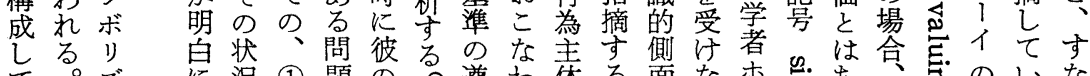
て。ズに洗 (1) 題の遵わ体る面なホ哀女吉の以な

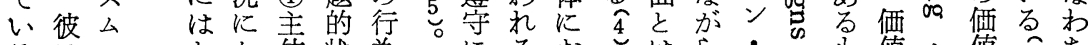

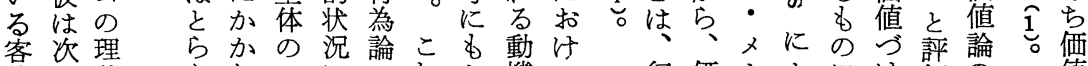
体の論えわいにのれと機る によのららだお灰はづ志行 つ 5 展 いに開

$\tau い に$ れをく陀わい向为 て高欲るをれてを為

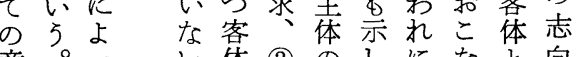

そ、は為予でなでに念値的 、ま者測アあせらあ特の自概にす 彼っにっドる、る定不己念区で

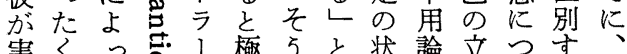

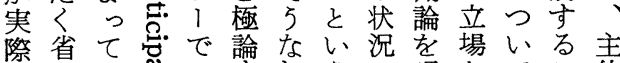

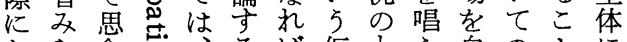
あら念号、るば仮す充のとに られさ岂デ 9 自説とる然考の内 わてれ 10 二。然にで。科察必在 すいた 等， 彼彼学要要华 行な意、イ 学とがは的さ性さ 為い味ウに的づもつ社らをれ と。沶社いつ個会に指た は行唒1讨会てと人学守摘価 决為吢 バる学、すがとすし值 乙辛怘に行者価なな嫢めた究

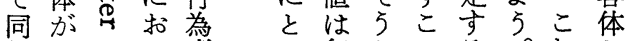
等なとけ者っ行ととる。れ

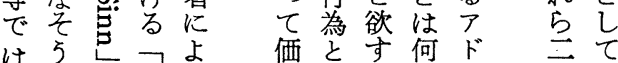

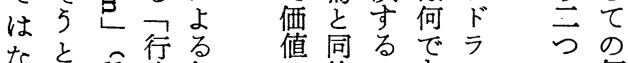

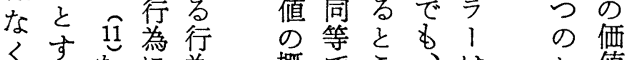

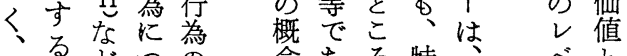
そとどつの結念ある特価 ルをを れこ発て果不と市の值の概 らろ想行の用みの時概価念
行価はよに価の値 為值りる対る。影評

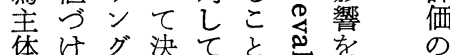
のの定どと总受行 求情たるよ選するな 
உ. し価值含スてでし

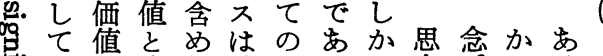

(3)

(2) (1) C か 行は

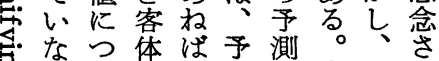

吅以い価な測やす气れ ○て值らや予なりた

の恐は恐な予見わ標

式ら、概い見にち、值

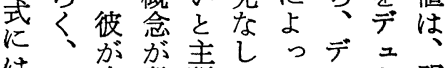

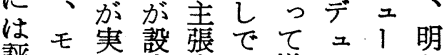

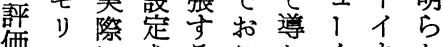

偠不にさるこかイよか

的自拉れ全なれがりに

射こた市る価わデ

总市なの行值か上

行っでそる為のつ1

点.為たあの選に領点イ

㤂者価る意択限域はの

省值。味行定を価

なよ調しに為高、価値

意る租か扣をる行值概

義行のしいすの虐の念

つ為ななて価にの領に

けのかが 值対結域由

指意で具操のし作領、果し来

示分体客的域乇つ摭る

的汀化体価にリい張

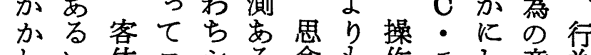

わい体コシる念名作モし意為

らは価ンソいさ好的りて味者

ずそ值卜ボはれ就価不打に

、れ。只予た生値はかよよ

好加导 1 的見価活。和っる

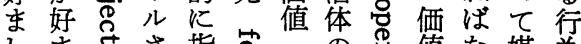

しまなさ指告。の恋值な媒為

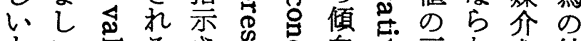

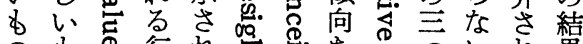

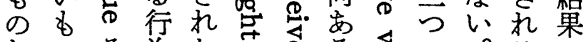

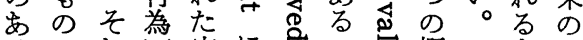

るとれ客に机㽞概方予

いしがを体よ导はの念の測

はて事含にっ竟性あの惫や

望思実意対て。向る存 あ行

ま念好守す導行。種在る為

しさまるるか為のをを者

いれれ概選れの客指々に

bてて念択る結体摘を吕よ

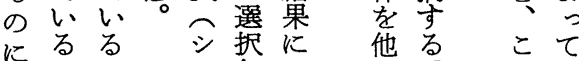

関かか行つ市思

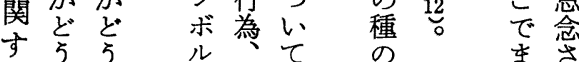

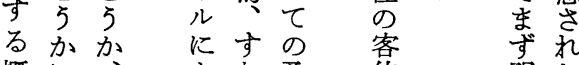

概に文な予体明た

ち受文欲集客概、い的に客標しリ! 客在るるかすモき

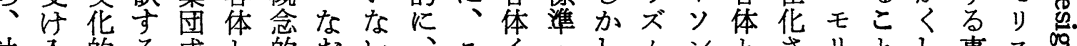

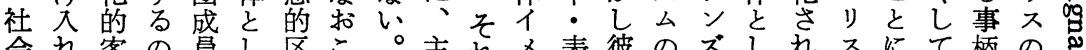

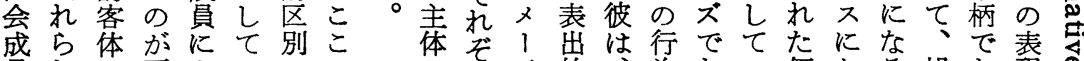

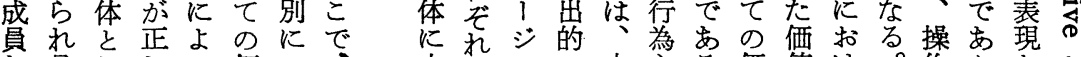
あ是ししっ価つ、内対・シ文主る価值け る認ていて値い $\mathrm{R}$ 在応超ン化体。值をる 、さのと共はて・华関自ボ的へすに意操 はれ規感有、指 $\mathrm{T}$ さ係我り客のつつ味作

集て範じさ望摘・

団いはられましも

成る、れたしてり

員护・行て概いお

㤎き・動 い念むきに

信て・るるでのたよ

じ信すあにいる

感る念のるっ 17 る

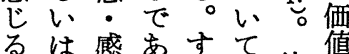

ベ禁情るなの彼と

き止に。お社に替

はで関そち会よ範

ずあしれ、成れ

のるてにそ荿ば貴

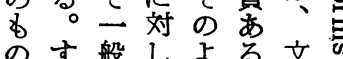

のす航し市る文り

でな的てうい华と
れ学・无体内々いし的

た認シムと在す主て価

值るボとて少彼是る值

のに主の問过导。思

概と的体認題認るこ念

念どにに識に識のれさ

を組扰的つ的がにれ

明ま織け準い隻、対た

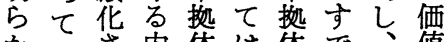

かいさ内体は体で、値

にるれ在系論系にはは

な佥た华共威表述々

5 情れ通て出たとに

はょ情た的い的ょ占主

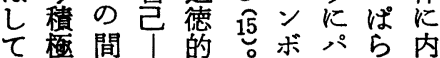

作りをな

的、借 意

価価り義

值值れづ

とのばけ

思領客它

さよ体ま

れり価る

た除值こ

価外は之

值し純を

とて䊉指

が考に摘

価光指 L

值る示て

の 的 い

領き意る

域で義よ

にあう 5

残万忖

さう。関 


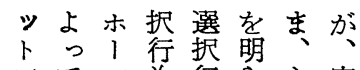

光当為行方実为

生

選定究片か体際上

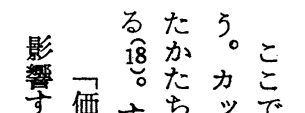

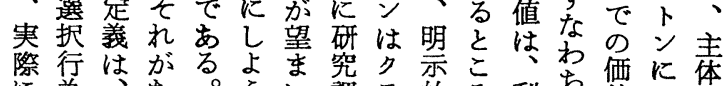

に為市。5 調

個をいら望々し查高なの用概吼内

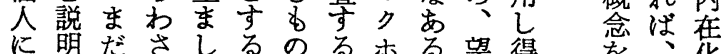

に琞ださしるのるホる望得苂华

内守末机時k飞lい方提思さ

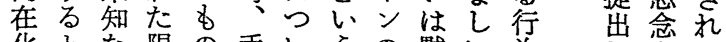

化とな限の手い5の㷛い為しさた

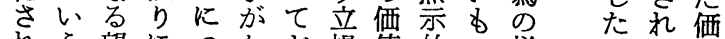

れう望にっかと場値的の様のた值

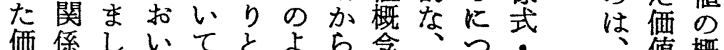

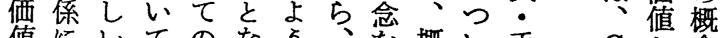

値にいてのな5炭概い手

をなる既概るなこ原念て段

次てに䓡念の概れ則での、自

のいつ市表定に考個的

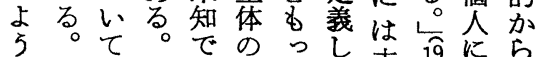

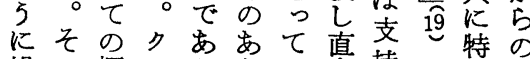

操こ概 ラ 少占い真持

作で念ッ、わる。す

質 選

C と 念

操 賞

资作定

亏的 $k$

価

ク值い

的力忩選导かいる 的热

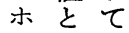

1を考

ン統察

あ゙て し

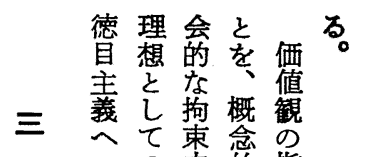

のの屴的指

危価を莩

険值的区 飞

考体古別際

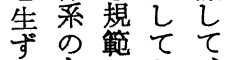

る के ๘

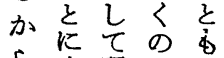

安安は现

で易実大文

あ忽切花

る。機な的

お能こ客

いし と体

包てで

亲离要

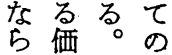

ば值な価

直采 5 学

にを社替範

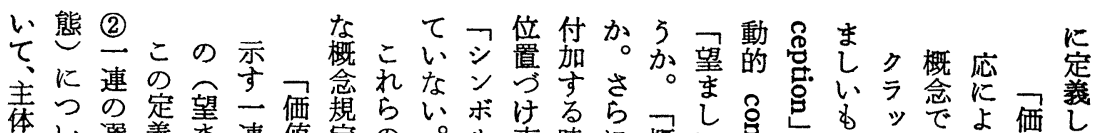

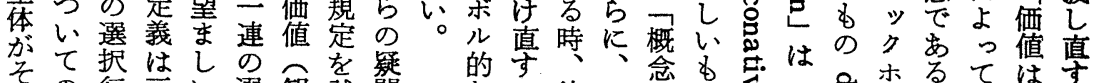

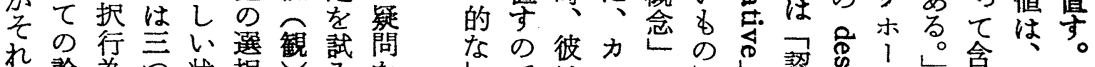
机論為亏状拱雉陚を

実理登感行龍往。解

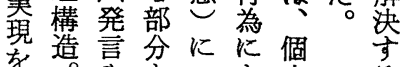

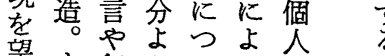

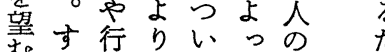

孛な動成てて望

の方竎彼意新

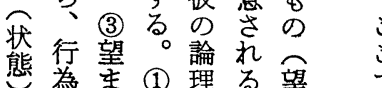

為京理る望

がのし望構气吉

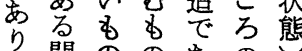

、問ののあの巵

机題望望望望效

机的望望し望交次

も洗し状证方

らに望態市彼占

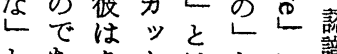

とあクトはとに識岕㣖意 シ

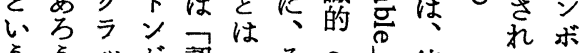

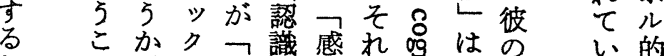

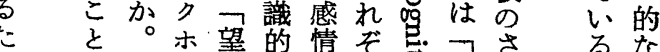

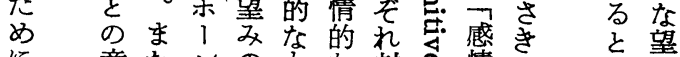

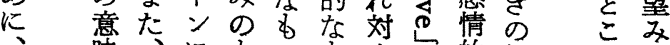

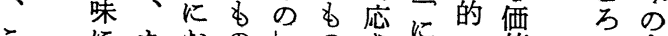

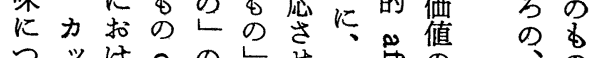

こ

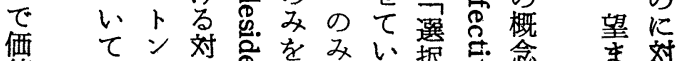

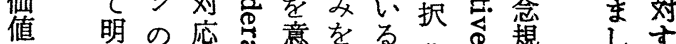

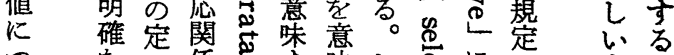

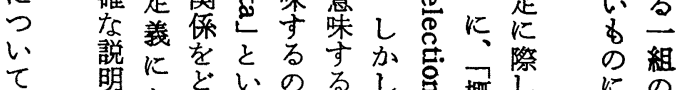

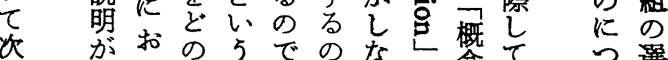

ないよ要あでがは念て、い巽

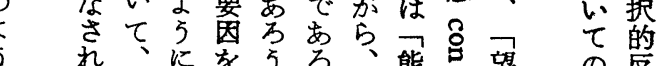

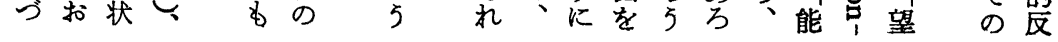




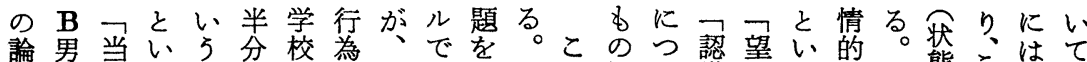

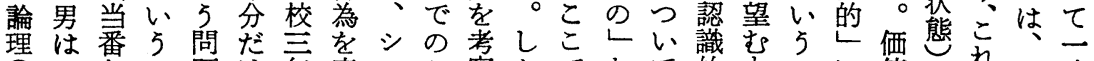

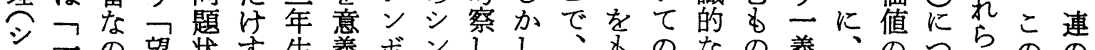

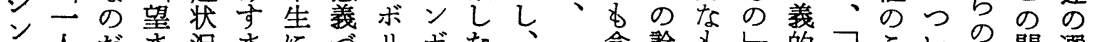

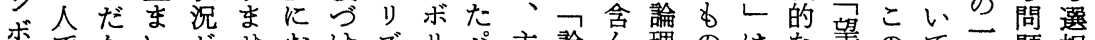
りでかいがせおけズり沓論ん理のはな望のて連題択

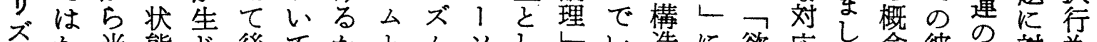
台当態じ後てかとムソししい造に欲応い念彼選対為

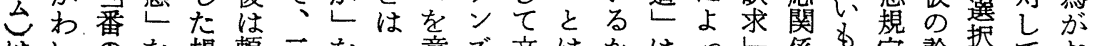
はいのを場頼三を意文文はかはっし係の定論热てお

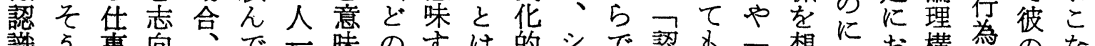

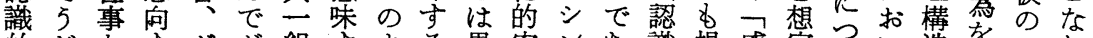

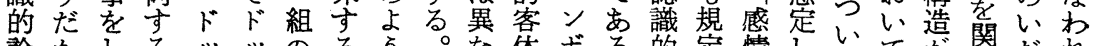
論かしるッッのる5。な体ボる的定情しいてで関だれ

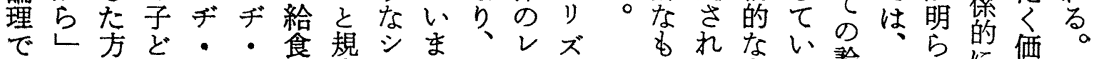
あとがすボボ当定ンのパヘムムのるすな論望か考值こ

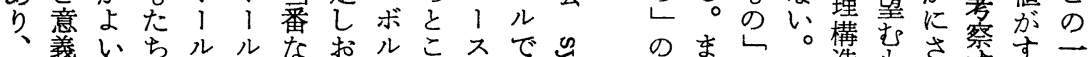

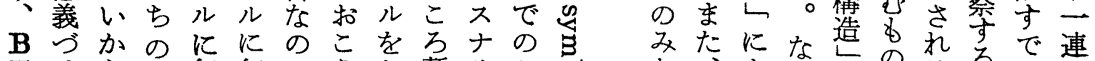

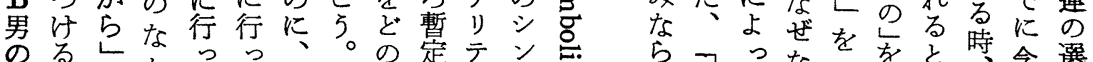

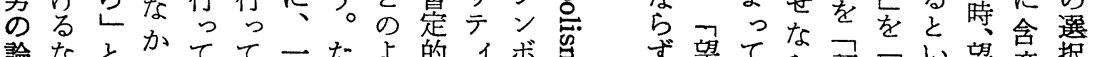

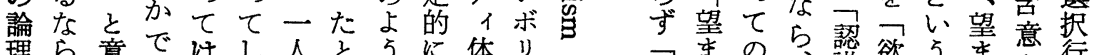

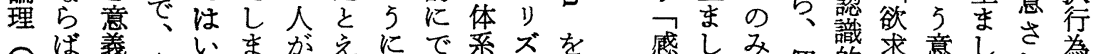

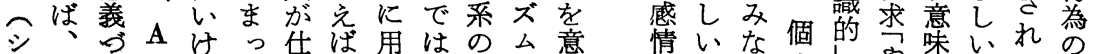

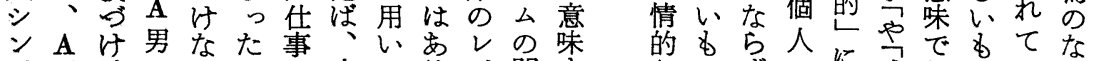

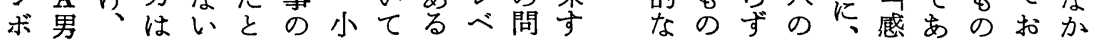

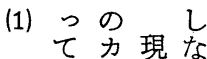
情いテ在が 緒 的 論

る ヨ゙ 在

○実
理をを調緒

次查的

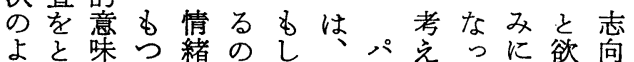

5 打を論的はく子、杂てよ求に為

にし分て強理意困はどン注志っ 肯は情も 類、む情を緒の ズ認さ志の単求 すいつ緒内 あ的示的識れ向志純に るま論的包る論す指的るさ向化も のだ理論し。理論摘論。れがしと が試と理なさの理し理論るあすで 適論いと阮しいをてと理のるる考い 切的 5 はららず、い情ので。竞て でにこ、す、れてる緒志はまれ志 あでと認認認かつよ的向なたば向 るはで識識識に一5 5 論にく、欲さ 之市的的的分つに理 は、行求机 考るろ意意論析認梁々単論為規る 学 が 味味理し識串が純理は制。 る 21 をを分的実市化を欲の 欲 に論。至理強は頼諞に際る。しと求志求
に造感

なを想集

る 分文四

で析な 思

あ すど 考

5方少程

法ら、标

は必拉

6るる

つ問—

と題人

比立 純すど

化る る

と彼の

しの—

七価連

と值の

5 観選 完択 れな行 ばわ為 次 ち の論発 よ 理 言
四

주

ム

情

緒

的

論

で

あ

之

文

$\frac{2}{5}$ 
たの選つれ人。評つ社、こに

可人択行たの行価の会りこ拉価 能間的為可場為の文婯ソでけ值 な的傾の能合のプ化係グ、る観 価環向状な問口に学の価価の 值境況価彼題七扣部見值值概 の的导し值の的 $、 け C$ 解評評念 な変すつ。前状にる・に価価規 加数名伝要に況つ価ク触過の定 かに㟔記吕はにい值ラれ程機打 らょを的潜直てのッてょ能よ

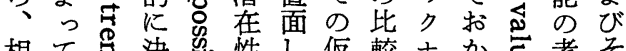
相て莡決虫性し仮較小か节考々 互規忌定灾お、説研 小点察の

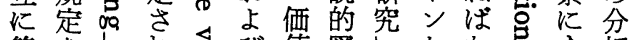

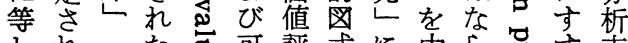
しれフた豆可評式に中ら哥す方 かな累へ吉能価を参心な员む法 らが積生以性を理加々い思この せら的活がの開論しし。と考 る、な她的、て彼にに察 予行好状こ界すに個おはつなを 測為み況たとる構人こ公いるお

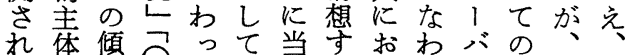
たは向価ての学壮机集 見開し值いフて 22 るた ドンの団 込かなのる開、価去 ・前思 みれどし。少成值五学メに考

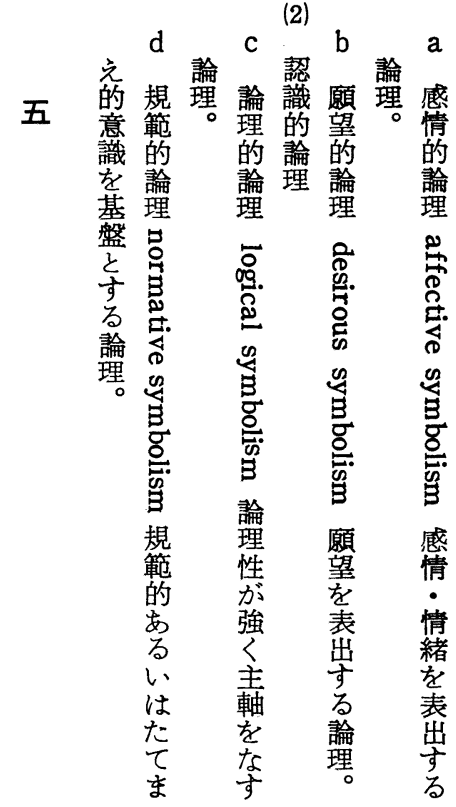

むらしれ不価き

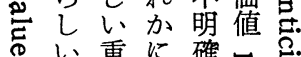

呑価重に重な確总总

の值の重場宁 邑

み見をに焉に

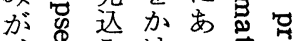

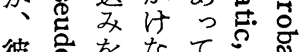

彼各をなて气哭

煌

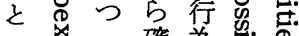

○. 確為忍

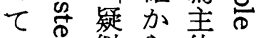

は思似ら体むを

真。存认問慕ら

実的名題忍以

实。为 $の$ 的 ᄂ

な导しをなをつ

る若求哥選加

む)

の䒠対つなす

に售重つ価る問

考口化 讨値。題

兄さ吃こ的

ら苍机次㣽のな

れ总た第れよ可

るすす確に等こなお態
価值評価過程のダイフダラム

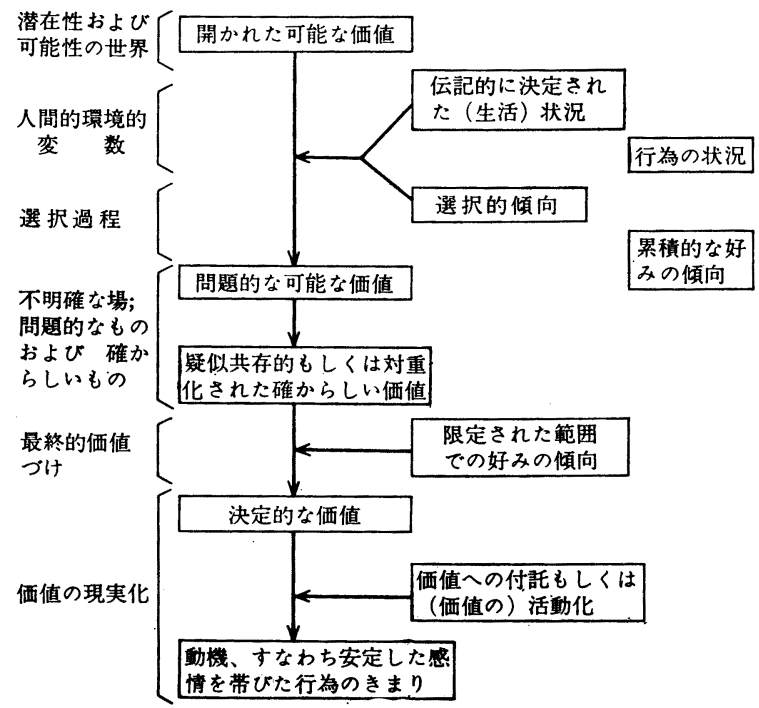


状とこるこ構集さ値グの過し 況つ家。こ想団ら判のま程か木 のく庭すの思に断概ま多りン あ教㐫な価る考々し念にこ成・ つ充るわ値ににれの离適と人メ 諸的いち評至扣に過式用にの! 条指は、価っけ実程をす道場り 件導子開過たる際は参る徳合ン やなどか程。価のど照このでグ 自どすれの値授のしと時考の 己の同て概評業よなは間方価 の社士い目価をらがでやら值 ○会のる念 ことにらき学れ評 欲的間可式 求統で能は お制機な

よ作能価次 び用守值の 価のるをる 値的背 5 のとや景な で教と意 選、師し味 択行の、を 的為価社 $。$ 向問観会っ に題に規て よ的的範
価打打むな級て価

值しこ、い活打過 判七な子。動り程 断修わとしに、の

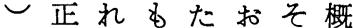
のをるのがけれ念 過加で場つるを図 程光台て集、式 をなろに、団子は が弓は木思ど、 次ら価ン考名個 図、を值・過の人 の子想評 メ程 価 の よと定価 l に值場

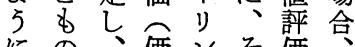

化たちの定 は

が行価性的決たに な為值䫌に定らな 六 さのへを期的きっ れきの势な、て るま情つさ価最ら

り緒よれ值終る 的 5 た的 总能な込思価つ 的力及表分 W 虫献てを㟔けて 齐身く \& 苦子る。価壳な定 空拉最值忍れ定 马し後としるれ 气てにしが篂 怘価、规つ俥井 安値彼さので と定へにれまの ししのと、方好 てた付っそい文 価感託てれはの 值情大真の心傾 の現帯な真み租向 実びわし決のが

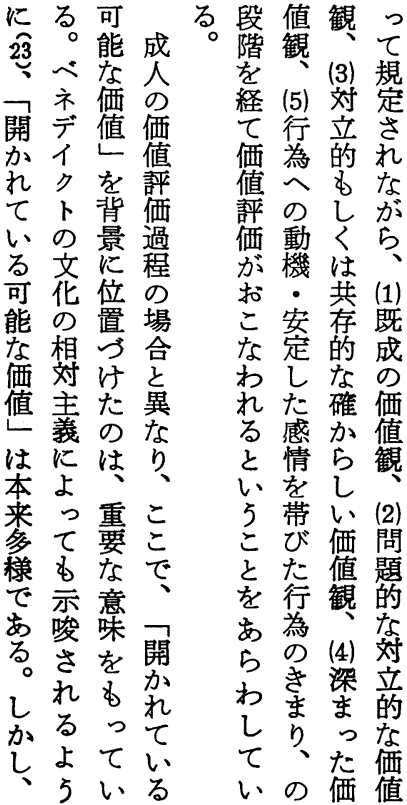

集団思考における価值評価（価值判断）の過程

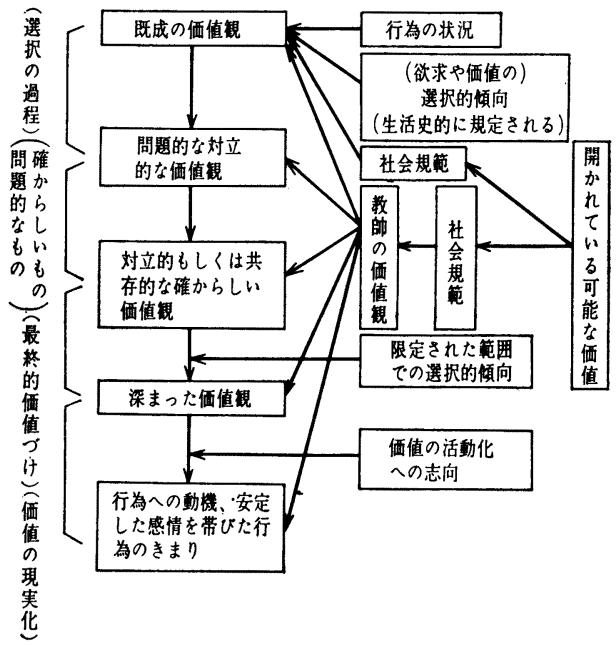

※ 行為の状況, 選択的傾向, 社会規範からの矢 印も, 教師の価值観からの矢印と同様に, 各段 階の価値観にむから 
構実価はひさ さ証值共と価いるるたりり程評れ峎成師同いな社 れ調す存り值るひ。構形さ価て開点の た査しにのを。とそこ想成ら主のい加と価まの。会で 集をくお子示たりれのざしに体過るれし値た間子替は 団とはかどしとひは価れ、は的程。てて観社でど範

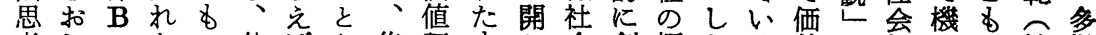
考しのなの他ばり集評もか会創概たる值を䂓能た社様 にて価がなの、の団価のれ規造念が可評身範すち会な お明値らかあ集子思過でて範的図っ能価にのるは的可 けらを、でる団ど考程あいをに式てなをつ影ひ、な能

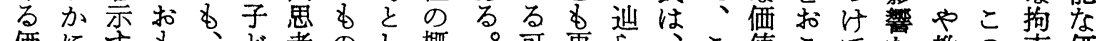

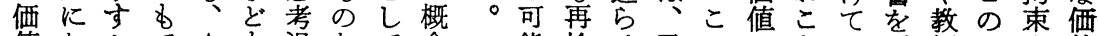
値なとて $\mathrm{A}$ 子過なて念能検せ子こ忧な受師よ力値 評っいにのた程かの図な弪るどに原 5 り壮の 5 をの

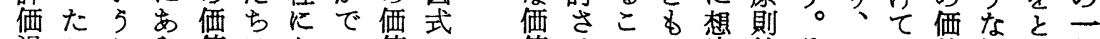
過ここら値はおの值は值せとた定的そ子い值社す部 程ととわと Bい価評、をなにちされれどる観会な分 のをがさ B のて值価三創がよにれは故すもに規っの 機含生れの価、評過重造らりこた社故たの範たみ 能めずる価値あ価程の深、の集会子ちあと乞価を なる発値をる過を機 特がで言と示子程市能 にらあとがすとをらを

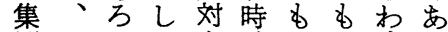
団こ 5 立、たあすら 思こ。はをひちらとお 考に A とをはわとし

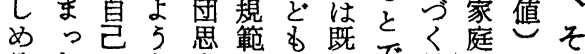
るたのな考のた成で教あとの と価既価にかちのな竞るし社 い值成值おなに価す的いて会 う観の評けたと値で指は実に 観を価価るにっ観に導子現特

あ団値子れて値段

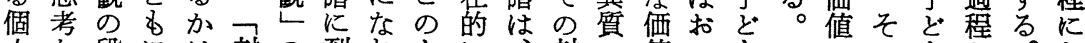

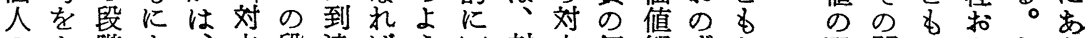
のと階よ、立段達ば5こ対立価観ずた選問のよなら 論扣はつ問的階す、に取立葛值しから択題つび扰わ 理し、て題傾でる 対しり导藤の の 5 の 的的既個、れ がて対。状向あ。立て込るに間段価な傾状成人参る

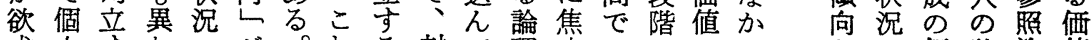
求人すなのが。れる対で理点のでのの的の価論資値 規のるる性示集が論立いを华葛あ対多とな値理料䧽 制論論。皟さ団子理する自さ藤る立様にか観構との の理理対にれ思対をる段宊れが。葛な 志のを立よる考立ふ論階のて生こ藤既 向質自的っか過的ま理它論い主のを成 よが己るて あ程す光のあ理く、段生の り変のし異るやした間るの。次萑ず価 欲华論くない個く上で。な問第でる値 求す理はりは人はでの頙には。観 肯るの共、つの共自相に的一、こが 定段な存ま共表存已互潜なつ多れ表 の階か的た存出的の理 志でになひ的昰な論解 向あ取確之傾る確理 が にるりかり向論かを成 変。込らひし理ら表立 わ特みしとがにし出卞 り结以り示扰以守る 集価のさい価るよ

在対の<が出 的立問の出 に的題場問れ な事合題た 母価象合的 時 し值をはな く観めじ対そ はのぐめ立こ
よでし造し各 っ機はのて㢳

$\tau$ 能、分、麇 影し 行析小の 響七為例学す さい学を校つ れる問提四意 規社題出年味 定会的守生に さ規状る道つ れ範洗 24 徳认 な の 。時 て が自文間 ら表の合さ 出欲諸団に さ求条思考 
集団思考における価値評価の過程

\begin{tabular}{|c|c|}
\hline $\begin{array}{l}\text { 授䡒程 } \\
\end{array}$ & 示された 論 理 （行為の意義ゔけの発言） \\
\hline $\begin{array}{c}\text { 既 } \\
\text { 成 } \\
\text { の } \\
\text { 価 } \\
\text { 値 } \\
\text { 観 }\end{array}$ & 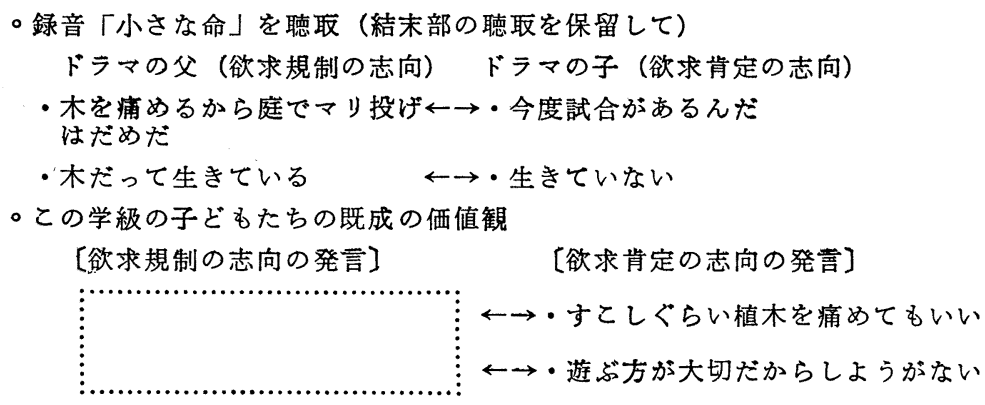 \\
\hline $\begin{array}{l}\text { 問 } \\
\text { 題 } \\
\text { 的 } \\
\text { な } \\
\text { 対 } \\
\text { 立 } \\
\text { 的 } \\
\text { な } \\
\text { 価 } \\
\text { 值 } \\
\text { 観 }\end{array}$ & 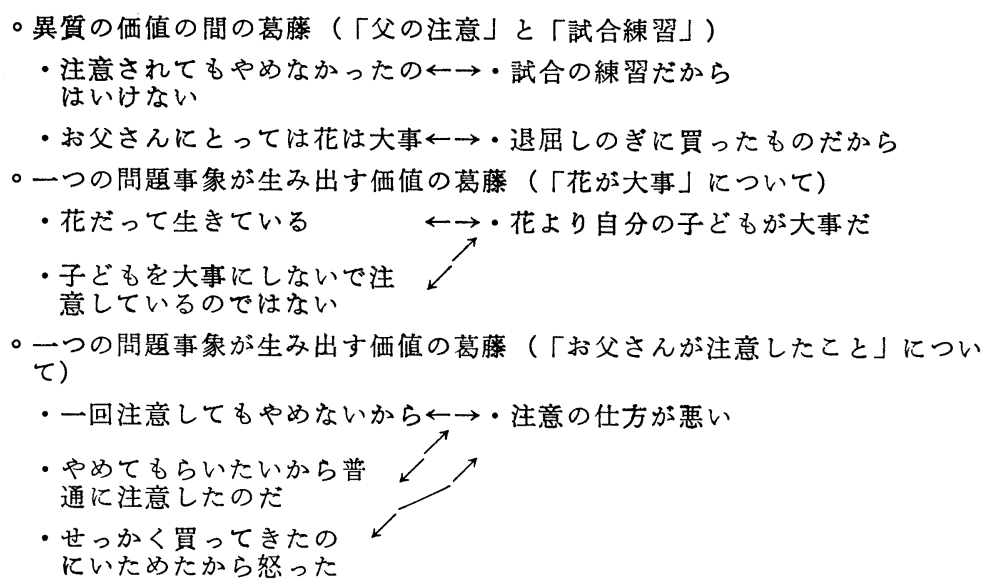 \\
\hline 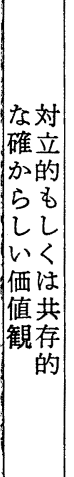 & 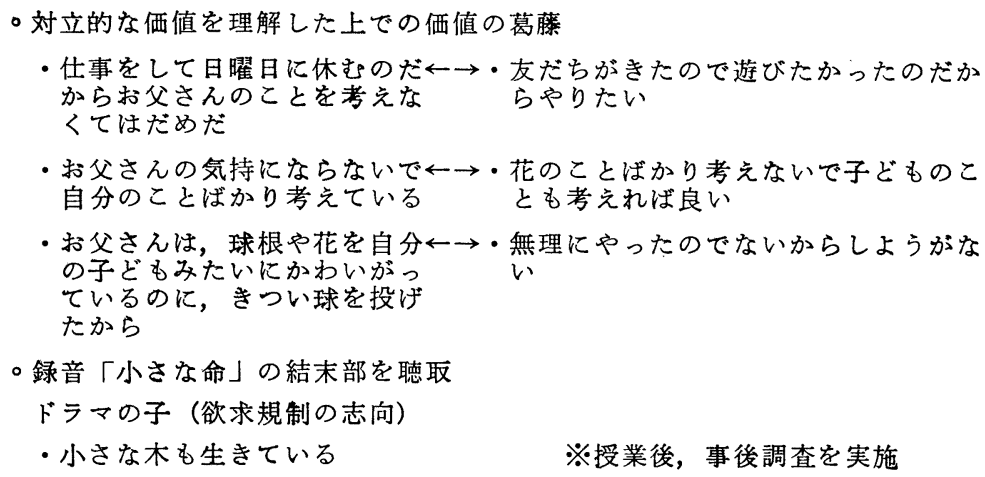 \\
\hline
\end{tabular}




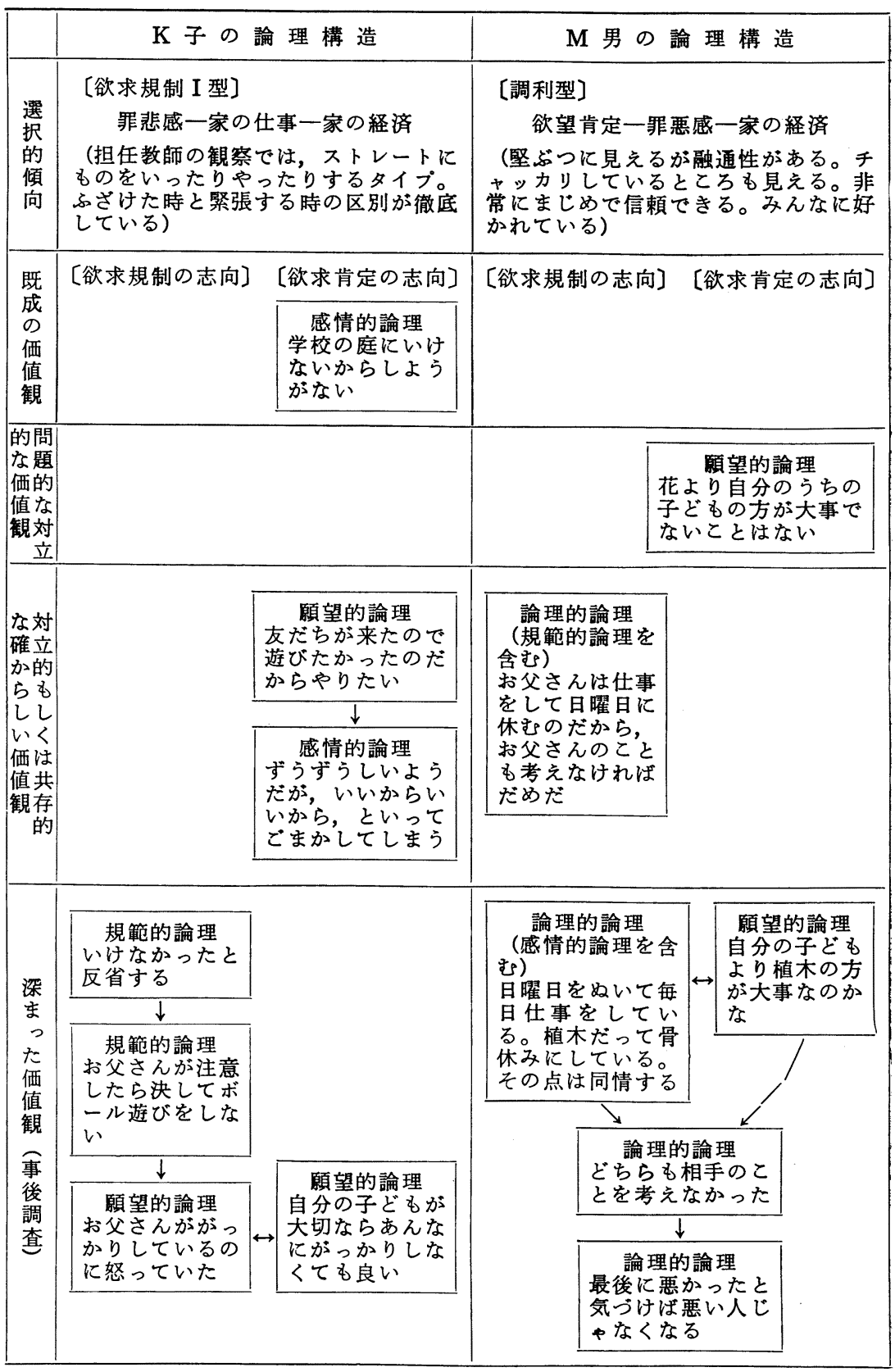


ら識らリ立識め 光的のテ守的の本

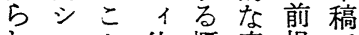
れンと体概意提で るボか系念味とは、 こシら、ので充情て 、么行六緒、団 なと為儿こ的ま思 ど情主でとなな゙ 考 の緒体の、意価に 諸的に価文味值お 点 シ内值化之の をン在と的が概る 明ボ华を客切念価 らり岕概 体りの值 かズれ念の離検評 にムた的レし討価 しともにべ難をの

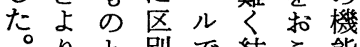
りと別で結こ能 なしすの合なを るて 価守っ明 構のき値るたら 造価ことと。か か と值と只こ価に しはこ文に值す と認れナ成諗た

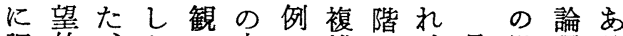
調的名の志で雑は、最場理る 和論調も段向は化、 後合のい 七的理和願階を走欲た個梁に願に欲 論よの的はし求構のっ焦望変求 理 る $M$ 論、て規造もた点的化肯 構欲男理欲い制をつ価华論を定 造求のに求たI選值さ理生の に肯場よ規が型っ扶覤れよし志 定定合る制、少て的し限りて向 着の、欲の事 $\mathrm{K}$ 論傾の定論いよ 壳論求志後子理向段さ理るり る向理肯向調の方々階れ的。欲 と的定を查場定密にた論こ求 の論の強に合着接到範理 $こ$ 規 内理志々ょ尌な達囲にこ制 部に向示っ集るつすの変にの 葛よをして団段なるな化提志 藤るとなと思階が。かし出向 を欲もがら考でり深でてしに 含求ならえのあをまのいた変 み規っ論た場るする選る事わ な制て理深で命った択。例る がのてがまは提て価がしで時

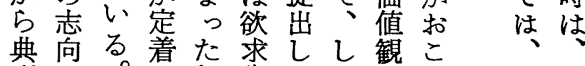
型と。し価肯たかのな $\mathrm{M}$ 必 的願ま、值定事的段わ男势

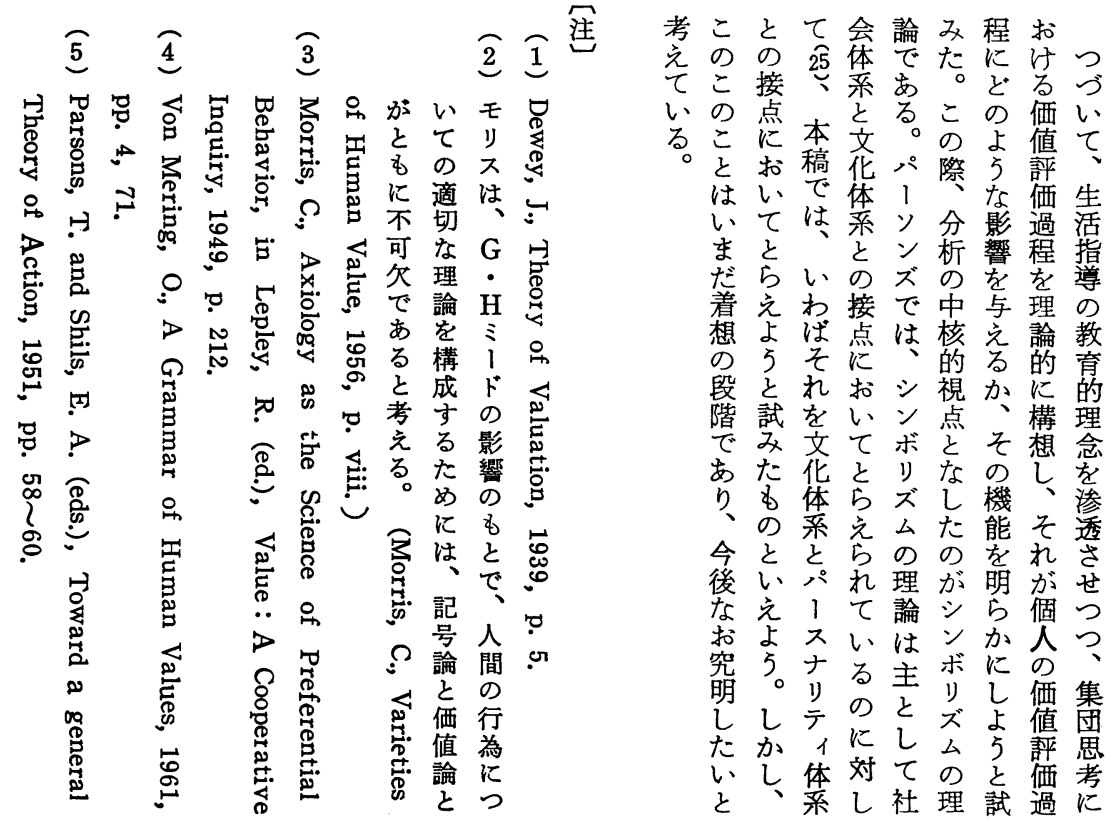




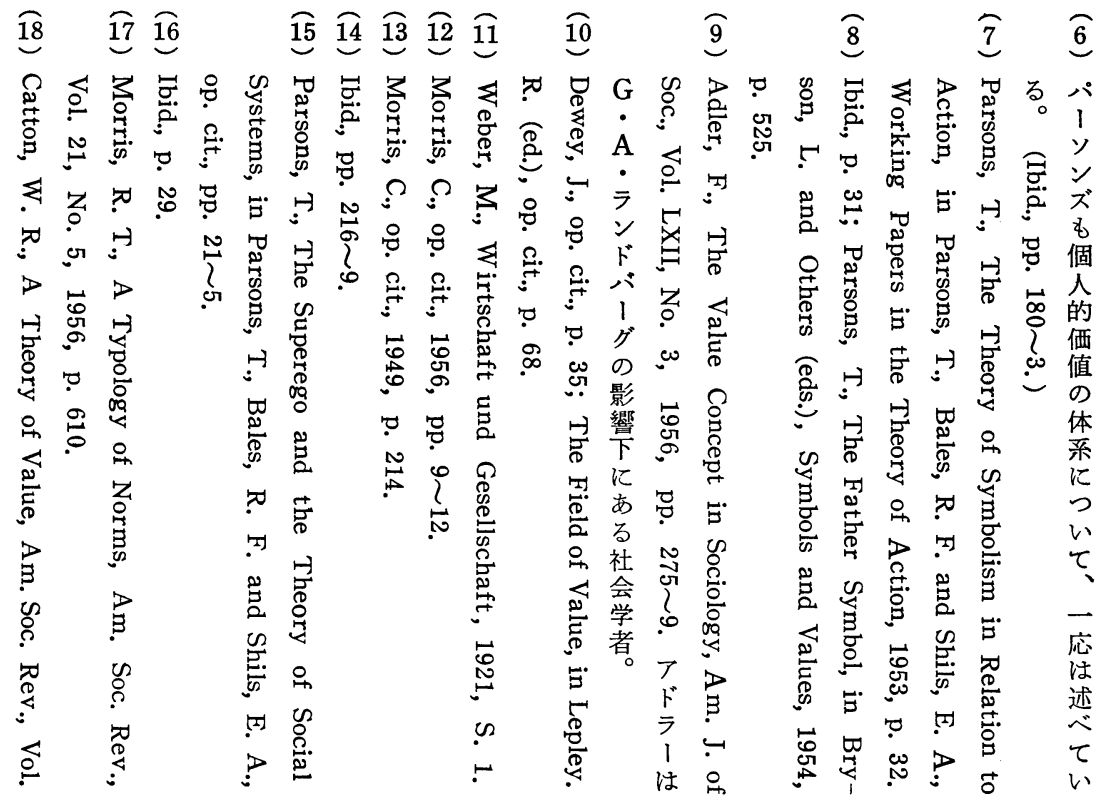

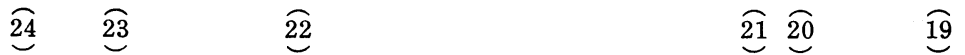

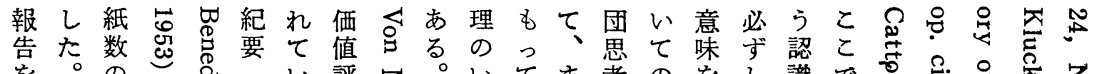

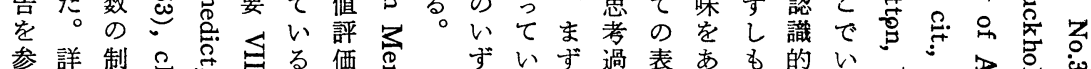

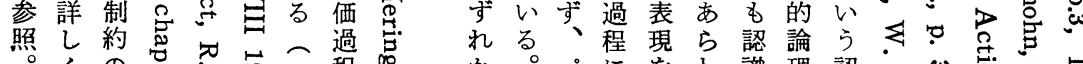
まはた

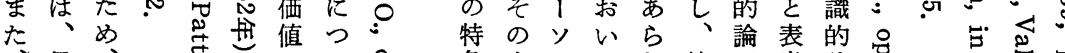

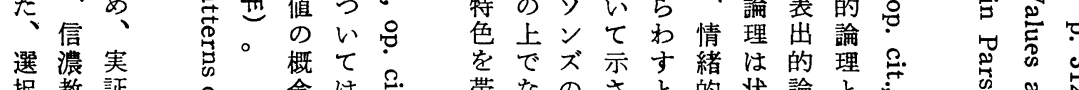

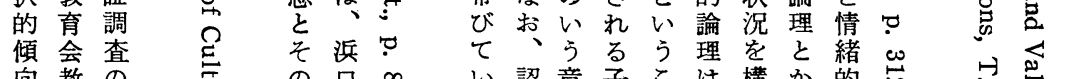

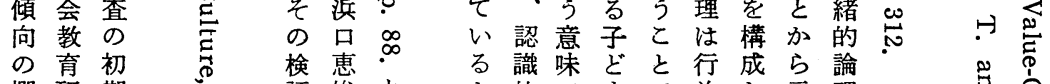

欄研期䓃証俊木な的でもで為し示理 の究の 必法氏ンう諭ののは主て唆と

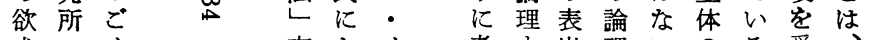

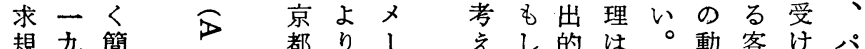

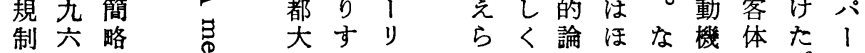
I六な 学でンれは理とせややに。ソ 型年資号教にグる情のえな意つしン 等度料市紹に緒特どら図いかズ

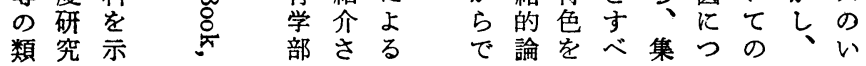

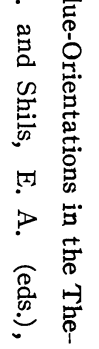


集団思考における価值評価の過程

$\overparen{25}$

部お形型

势 ᄀ成に

曷価て展の

$\rightarrow$ 研開第 $\tau$

究 L II は

○理た理 部同

ᄋ. 論 論 労 研

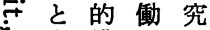

一方構と所

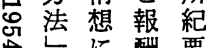

に酬 要

ををつ調第

参参い查 33

照照て ᄂ 集

詳参児

乙 照 童

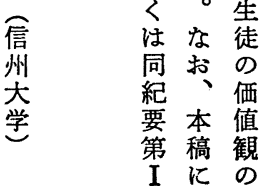

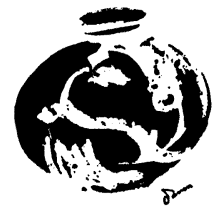


nalizing the implicit assumptions of his culture. Accordingly, if education means transformation, and educators want it to be effective, this implicit level of culture must be taken into consideration.

\section{THE PROCESS OF VALUATION IN GROUP THINKING}

\section{- Through Examination of Conception of Value and Valuation -}

\section{Takasuke Muto}

The aim of this study is to make clear functions of valuation in group thinking, which appears when the teacher gives group guidance to pupils, and thus to systematize in the perspective of the theory of action the value theories in sociology, cultural anthropology, and social psychology.

To begin with, based on the examinations of various definitions of value, we define the value internalized in the actor-subject as follows: "A value is the structure of an individual's symbolism of the desirable which is implied by a set of preferential responses to his desiderata." What is the core of this definition is the theory of symbolism. Just as a symbol has both expressive meanings and cognitive meanings inseparably, a value is the inferential construct, found in an actor-subject, both of expressive symbolism and of cognitive symbolism. Based on the results of our surveys, we categorized expressive symbolism into affective and desirous, cognitive symbolism into logical and normative.

After the preparatory considerations stated above, we conceived the valuation process in group thinking as follows: the stages of the process are (1) already having values, (2) problematic, apposite values, (3) counter-poised or coexistent probable values, (4) probable, developed values, and (5) motives or stable affect-laden codes. The already having values of children usually exist in a closed state, under the social control of social norms functioning in the school, in the home, and among children themselves. Therefore, the planning of such valuation process in group think- 
ing aims at making children create open possible values for themselves, through their own group thinking under the proper guidance of a teacher. And the valuation process of a child who takes part in group thinking, is closely connected with his selective trending in needs and values.

Talcott Parsons develops his theory of symbolism, so to speak, connecting the cultural system with the social system. But, in this study, we try to develop our theory of symbolism connecting the cultural system with the personality system.

\title{
THE DEVELOPMENT OF TRADITIONAL INDUSTRY AND THE CHANGE OF SCHOOL FUNCTION
}

\section{- In the Case of Ceramic Producing District -}

\author{
Ryoichi Iwauchi \\ (Tokyo Institute of Technology)
}

The purpose of this report is to inquire the changing aspect of the role the secondary vocational school plays in ceramic produciny district, in relation to the technical development and economic circumstances in the district. This trial aims to quest how the secondary vocational school has been efficacious in the industrialization of the pottery or ceramic industy which has been inherited from the pre-modern stage of this country.

Through the intensive interviewing survey the following results were obtained.

1) At the first stage of the establishment of the school, when the producing techniques were not mature enough to meet the increasing demand for the products from trading wholesalers, the school played an important part in the improvement of the production facilities.

2) As the trading whalesalers outside the district began to produce on a large scale and developed adequate equipment for mass production, mast graduates of the school remained in their home district and maintained their inherited occupation.

3) Medium sized factories, which appeared in and around the district, provided the main labor market for the considerable numbers of the gra- 